\title{
Effect of compost/water ratio on some main parameter of compost solutions
}

\author{
Nikolett Éva Kiss ${ }^{1,2}$ - Edit Gorlizay ${ }^{2}$ - Péter Tamás Nagy ${ }^{2}$ - János Tamás ${ }^{2}$ \\ ${ }^{1}$ University of Debrecen, Doctoral School of Animal Science \\ ${ }^{2}$ University of Debrecen, Faculty of Agricultural and Food Sciences and Environmental Management, Institute of Water and Environmental \\ Management, Debrecen \\ kiss.nikoletteva@agr.unideb.hu
}

\begin{abstract}
SUMMARY
Composting is an efficient technology for the utilisation of by-products and waste. It is also suitable for treating raw materials to convert fertilisers that are not recommended for application without pre-processing. Such is the case with poultry manure, which is very important to pre-treat due to its hazardous properties. An increasingly common form of compost is compost tea, which is made by soaking compost in water. In our experiment, we made compost tea from a composted and granulated poultry manure product. Three mixing ratios were used (1/5, 1/10, 1/10) and compost teas were set for three different extraction times (24-48-72 hours). After elimination of the experiment, the pH, EC, and nitrate and ammonium contents of the samples were measured. The aim of this study was to determine whether there is a difference between each mixing ratio and different extraction times. Based on our results, it can be said that the fluctuation of pH values during the experiment was low. Regardless of the mixing ratio and extraction time, the samples were in the slightly acidic range. The electrical conductivity, nitrate and ammonium content follow a similar trend, the values decrease significantly with the increase of the mixing ratio. Similar tendency was observed at the incubation time. The concentrations of both EC and nitrogen forms increase with increasing incubation time, in most cases significantly.
\end{abstract}

Keywords: compost tea; poultry manure; plant nutrition

\section{INTRODUCTION}

Poltry manure is a very high nitrogen content, fiberrich feces. Pretreatment is essential before use in the field. Composting is a long-used method of organic waste and by-products. During this biological process, the organic matter of wastes and by-products decomposes into simple compounds $\left(\mathrm{CO}_{2}, \mathrm{H}_{2} \mathrm{O}, \mathrm{SO}_{4}\right.$, $\mathrm{NO}_{3}$ ) and transformed a humus-like substance with adequate moisture and oxygen content (Epstein, 1997; Alexa and Dér, 2001; Sulzberger, 2006). Composting technology plays a major role in sustainable agriculture through the recovery of waste and potential pollutant (Sequi, 1996).

There is little literature on composting poultry manure, as its unfavorable properties (high nitrogen, fiber and moisture content) are not conducive to composting. The Hosoya fermentation system is suitable for composting by-products with unfavorable properties (Georgakakis and Krintas; 2000). The system is based on fermentation and drying. By the end of the process, granules with a dry matter content of 80 85\% are obtained (Hosoya \& Co., 1996; Csiba and Fenyvesi, 2012; Szabó, 2016). The advantages of granulated products are that heat treatment eliminates harmful ammonia gases, destroys weed seeds and pathogen bacteria (Gaál, 2011).

In the course of my research, I produced compost tea from a composted and granulated poultry manure product that was produced using Hosoya fermentation technology. Compost tea, also known as compost solution is nn increasingly common use of compost. Compost teas are a liquid form of compost preparations made by soaking organic matter in water. Zaccardelli et al. (2018) states that compost tea can be extracted from compost by extraction with water. Compost tea can be made with or without aeration and with the addition of additives to enhance microbiological life (Scheuerell and Mahaffee, 2002; Ingham, 2005). Compost solutions can be sources of microbial biomass, organic matter, organic acids, soluble mineral nutrients, and plant growth regulators (Shrestha et al., 2012; Edwards et al., 2013; Kim et al., 2015; Pane et al., 2016; Sujesh et al., 2017). Due to the diversity of compost tea and the spread of organic and sustainable farming, more and more researchers have begun to address compost teas (Litterick et al., 2004).

Different compost/water ratios and different incubation times were used in the experiment. My aim was to compare the effects of different ratios and times on the content parameters of the solutions.

\section{MATERIALS AND METHODS}

The experiment was performed at the laboratory of Institute of Water and Environmental Management. A composted and then granulated poultry manure product as a raw material was used for the compost tea. The product was produced in the manure processing plant owned by Baromfi-Coop Ltd. The main characteristic of the broiler manure compost are reported in Table 1.

The experiment was set up with 3 compost/water ratios (CWR) $(1 / 5,1 / 10,1 / 20)$, set at 3 incubation temperatures $\left(20-35-50^{\circ} \mathrm{C}\right)$ and 3 different extraction time (24-48-72 hour). The glass jars used for the compost teas were sterilised in autoclave before the experiment. After mixing the solutions, they were placed in an incubator at the given temperature for a given time. 
Table 1. Chemical properties of compost product for compost tea extraction

\begin{tabular}{lccc}
\hline Compost parameters & Value & Compost parameters & Value \\
\hline Moisture content $(\mathrm{m} / \mathrm{m} \%)$ & 12 & $\mathrm{~S}\left(\mathrm{~m} / \mathrm{m}^{-}\right)$ & 1 \\
$\mathrm{pH}$ & 7.2 & $\mathrm{~B}\left(\mathrm{mg} \mathrm{kg}^{-1}\right)$ & 31.4 \\
TDS $(\mathrm{m} / \mathrm{m} \%)$ & 73 & $\mathrm{Fe}\left(\mathrm{mg} \mathrm{kg}^{-1}\right)$ & 545 \\
Nitrogen $(\mathrm{m} / \mathrm{m} \%)$ & 5.5 & $\mathrm{Mn}\left(\mathrm{mg} \mathrm{kg}^{-1}\right)$ & 374 \\
Phosphorus $(\mathrm{m} / \mathrm{m} \%)$ & 3 & $\mathrm{Mo}\left(\mathrm{mg} \mathrm{kg}^{-1}\right)$ & 3.66 \\
Potassium $(\mathrm{m} / \mathrm{m} \%)$ & 2.5 & $\mathrm{Zn}\left(\mathrm{mg} \mathrm{kg}^{-1}\right)$ & 367 \\
$\mathrm{Ca}(\mathrm{m} / \mathrm{m} \%)$ & 6 & $\mathrm{Cu}\left(\mathrm{mg} \mathrm{kg}^{-1}\right)$ & 53.3 \\
$\mathrm{Mg}(\mathrm{m} / \mathrm{m} \%)$ & 0.5 & & \\
\hline
\end{tabular}

Source: Baromfi-Coop Ltd., 2018.

After the extraction time, the solutions were centrifuged. For centrifuged samples, $\mathrm{pH}$ and electrical conductivity (measured is $\mathrm{mS} \mathrm{cm} \mathrm{cm}^{-1}$ units) of the solutions were measured with a HANNA HI 2550 laboratory instrument. Inorganic nitrogen forms (nitrate, ammonium) in the compost solution were measured with a PF-12Plus photometer and Visocolor ECO reagents. Measurements were performed in 3 replicates.

Statistical analysis of the data was performed using $\mathrm{R}$ software. The normal distribution of the data was examined by Shapiro-Wilk test. If the data proved to be normally distributed, I used Duncan's test to quantify the statistical differences at a significance level of 5\% $(\mathrm{p}=0.05)$. If the groups were not normally distributed, I used the Kruskal-Wallis test.
In the present study, the evaluation of the results was based on CWR and incubation time. Thus, incubation temperature was excluded from the evaluation because there was no significant effect on treatments based on preliminary evaluations.

\section{RESULTS AND DISCUSSION}

\section{The pH and electrical conductivity values of compost teas}

Based on several authors, the totality of watersoluble compounds can be estimated based on $\mathrm{pH}$ and electrical conductivity (Martinez-Suller et al., 2010; Abbey et al., 2013). Accordingly, measurements were started with these parameters.

\section{Figure 1. The $\mathbf{p H}$ values of compost teas with different compost/water ratios and extraction time}

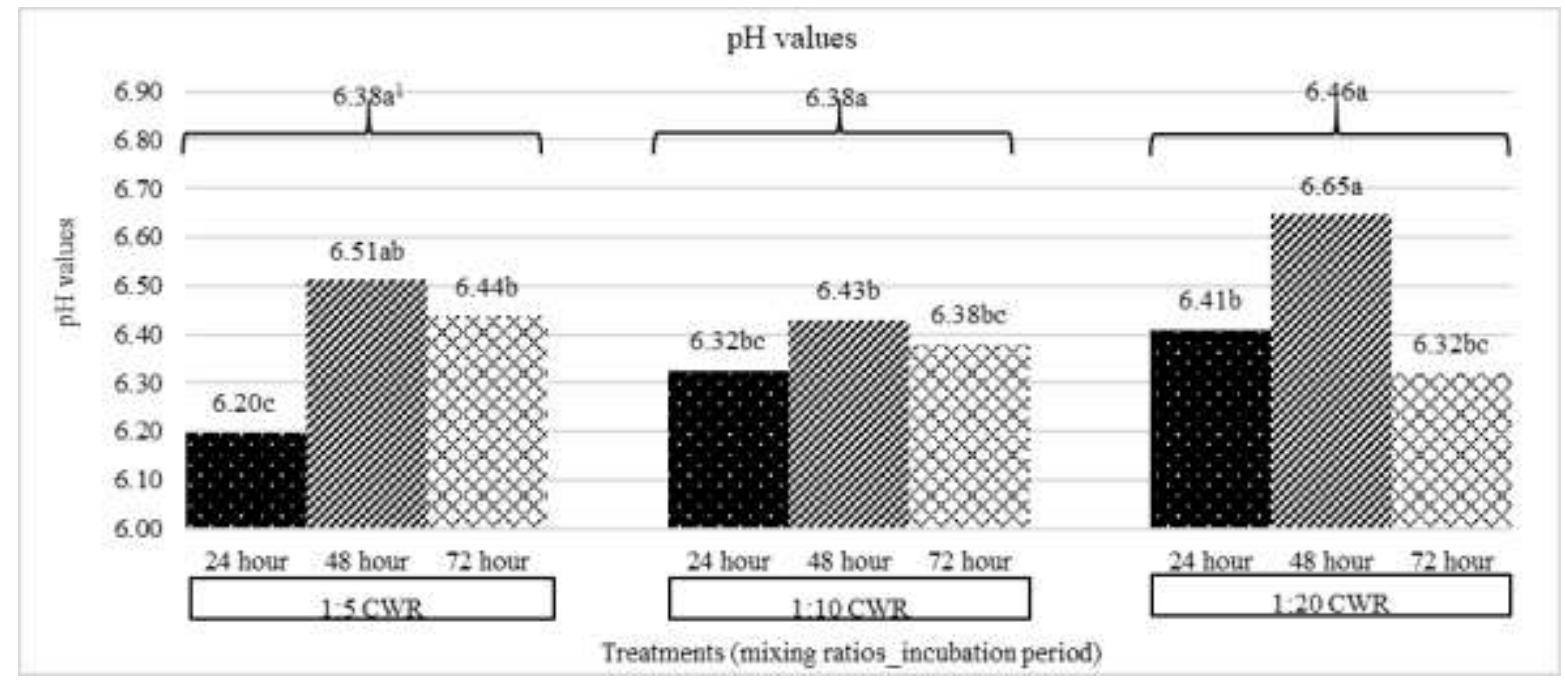

${ }^{1}$ Bars with the same letter are not significantly different $(\mathrm{p}=0.05)$

As shown in Table 1 the $\mathrm{pH}$ of the raw material is near neutral $(\mathrm{pH}=7.2)$, while the $\mathrm{pH}$ of compost teas are slightly acidic (Figure 1) similar to the results of other authors (Islam et al., 2016; Gorliczay et al., 2019). Fluctuations in $\mathrm{pH}$ values were low during the experiment. The highest average $\mathrm{pH}$ was measured at the compost/water ratio $1 / 20 \quad(\mathrm{pH}=6.46)$, but no significant difference was observed between the $\mathrm{pH}$ of each mixing ratio.

Considering the incubation time, the $\mathrm{pH}$ of the twoday solutions was the highest for all three ratios and then decreased slightly to the third day. Within the ratios, there was no significant difference between each incubation time. 
Figure 2 illustrates the changes of electrical conductivities of compost tea with different compost/water ratios and extraction times.

Based on the results, the electrical conductivity decreased significantly with increasing compost/water ratio. While the EC at a ratio of $1 / 5$ it was $17.34 \mathrm{mS} \mathrm{cm}^{-1}$, at $1 / 10$ it was $11.64 \mathrm{mS} \mathrm{cm}^{-1}$ and at
$1 / 20$ it was already $6,46 \mathrm{mS} \mathrm{cm}^{-1}$. Gorliczay et al. (2019) also found that compost with a lower incorporation rate has higher conductivity. The effect can be explained by the presence of larger amounts of dissolved anions in the more concentrated solution, which also increases the conductivity.

Figure 2. Electrical conductivity $\left(\mathrm{mS} \mathrm{cm}^{-1}\right)$ of compost tea with different compost/water ratio and extraction time

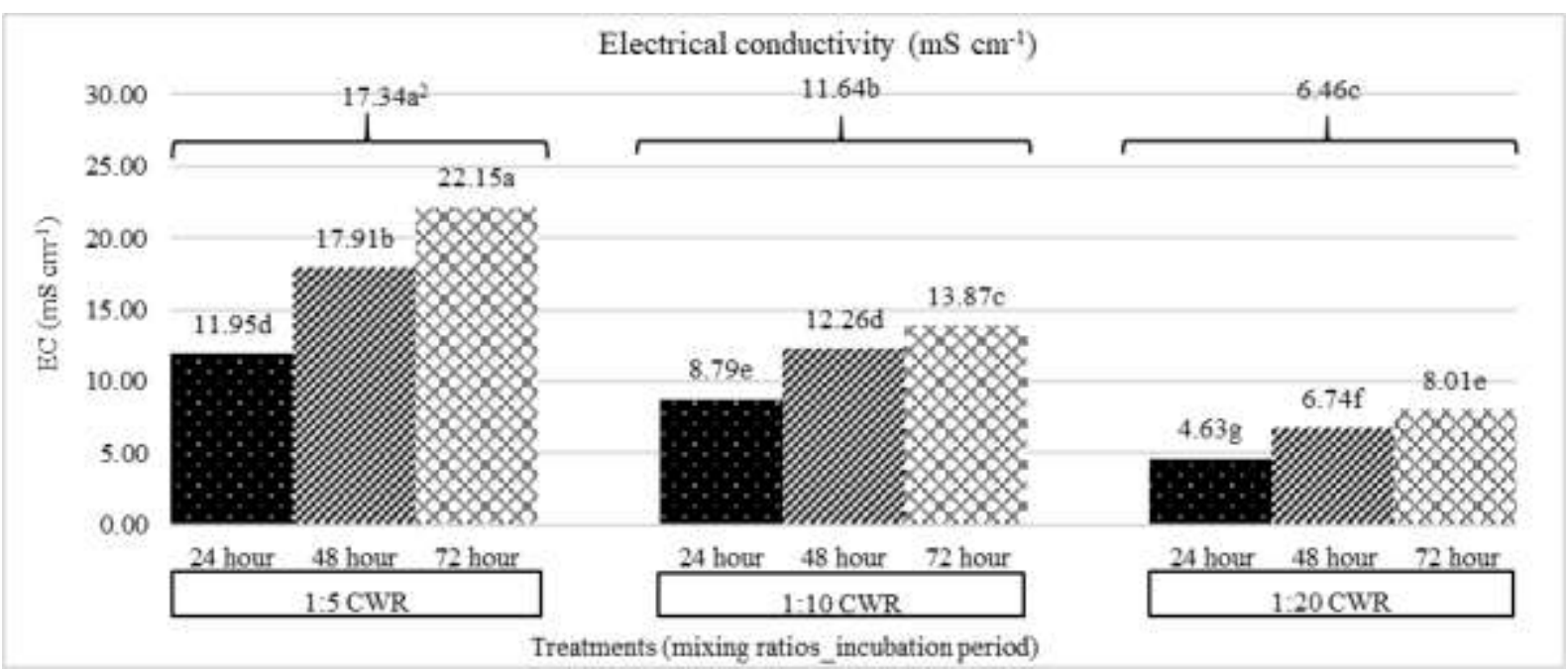

${ }^{2}$ Columns with different letters are significantly different $(\mathrm{p}=0.05)$

The conductivity of compost teas incubated for three days was significantly higher than the solutions incubated for a shorter time. Our findings are similar to those obtained by Kim et al. (2015) and Islam et al. (2016) who also found that as the extraction time increased, the EC also increased. This can be explained by the increasing of the total dissolved solids (TDS) with increasing extraction time.

\section{Nitrogen forms (nitrate, ammonium) of compost} teas

Beside of $\mathrm{pH}$ and $\mathrm{EC}$ of compost tea solutions the main inorganic forms of nitrogen (ammonium and nitrate) were also determined in the experiment.

Figure 3 shows the nitrate concentration $\left(\mathrm{mg} \mathrm{l}^{-1}\right)$ of compost teas with different compost/water ratios and extraction time.

Figure 3. Nitrate concentration $\left(\mathrm{mg} \mathrm{l}^{\left.\mathbf{l}^{-1}\right)}\right.$ of compost tea with different compost/water ratio and extraction time

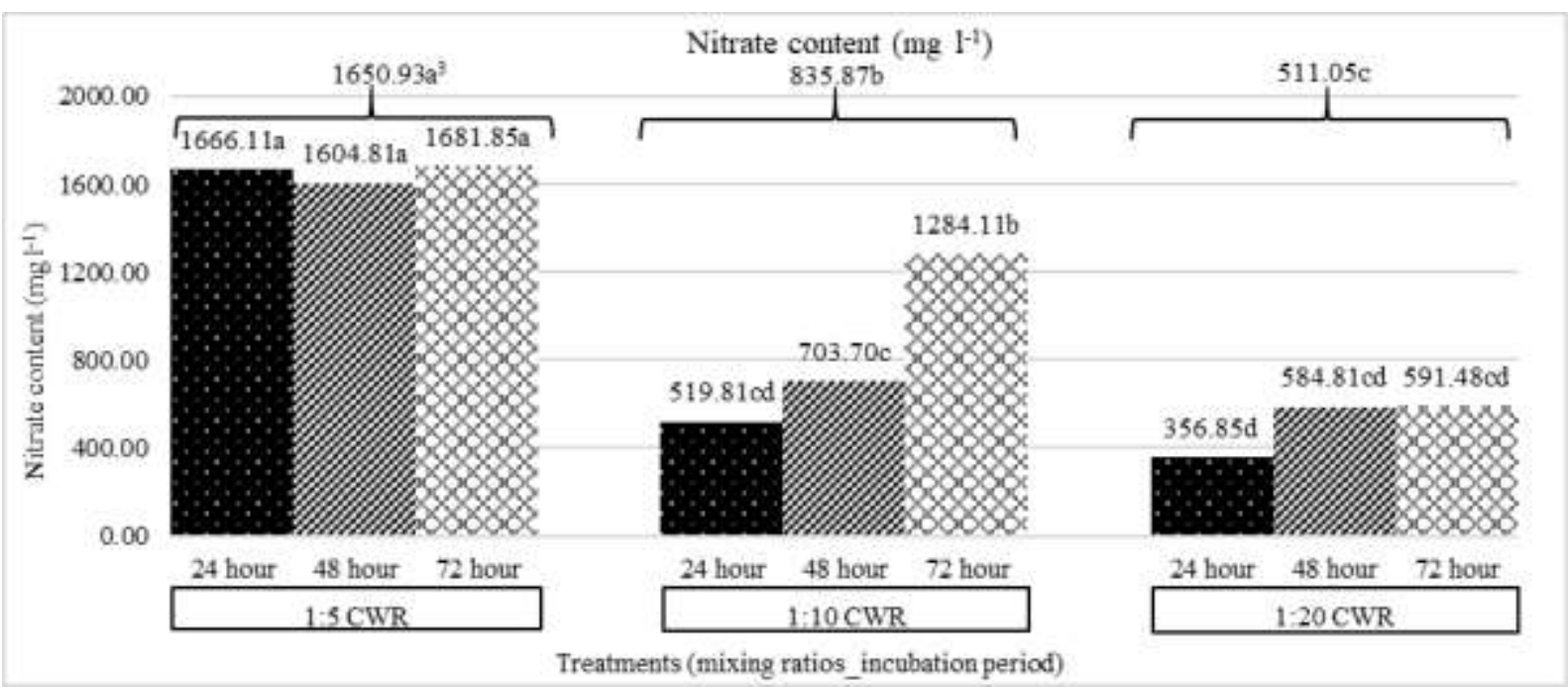

${ }^{3}$ Different letters indicate significant differences between mean $\mathrm{p}=0.05$ 
As the Figure 3 shows as the mixing ratio increased, the nitrate content decreased significantly. At a mixing ratio of $1 / 5$, the nitrate content remained very stable regardless of the incubation time. There was no significant difference between extraction times.

Nitrate content of $1 / 10$ CWR solutions were significantly lower compared to $1 / 5$ ratio. At this ratio, the incubation time had a very significant effect on the nitrate content. While the nitrate concentration was
$519.81 \mathrm{mg} \mathrm{l}^{-1}$ in the 24 hour solution, it was 1284.11 $\mathrm{mg} \mathrm{l}^{-1}$ in the 72 hour solution.

The trend was similar for the $1 / 20$ solutions. The nitrate concentration was $356.85 \mathrm{mg} \mathrm{l}^{-1}$ in the one-day solution and $591.48 \mathrm{mg} \mathrm{l}^{-1}$ in the three-day solution.

Overall, more concentrated solutions have a higher nitrate content. Furthermore, over a longer extraction time, more nitrate is dissolved from the compost.

Figure 4 shows the results of the ammonium concentration measurement.

Figure 4. Ammonium content $\left(\mathrm{mg} \mathrm{l}^{-1}\right)$ of compost tea with different compost/water ratio and extraction time

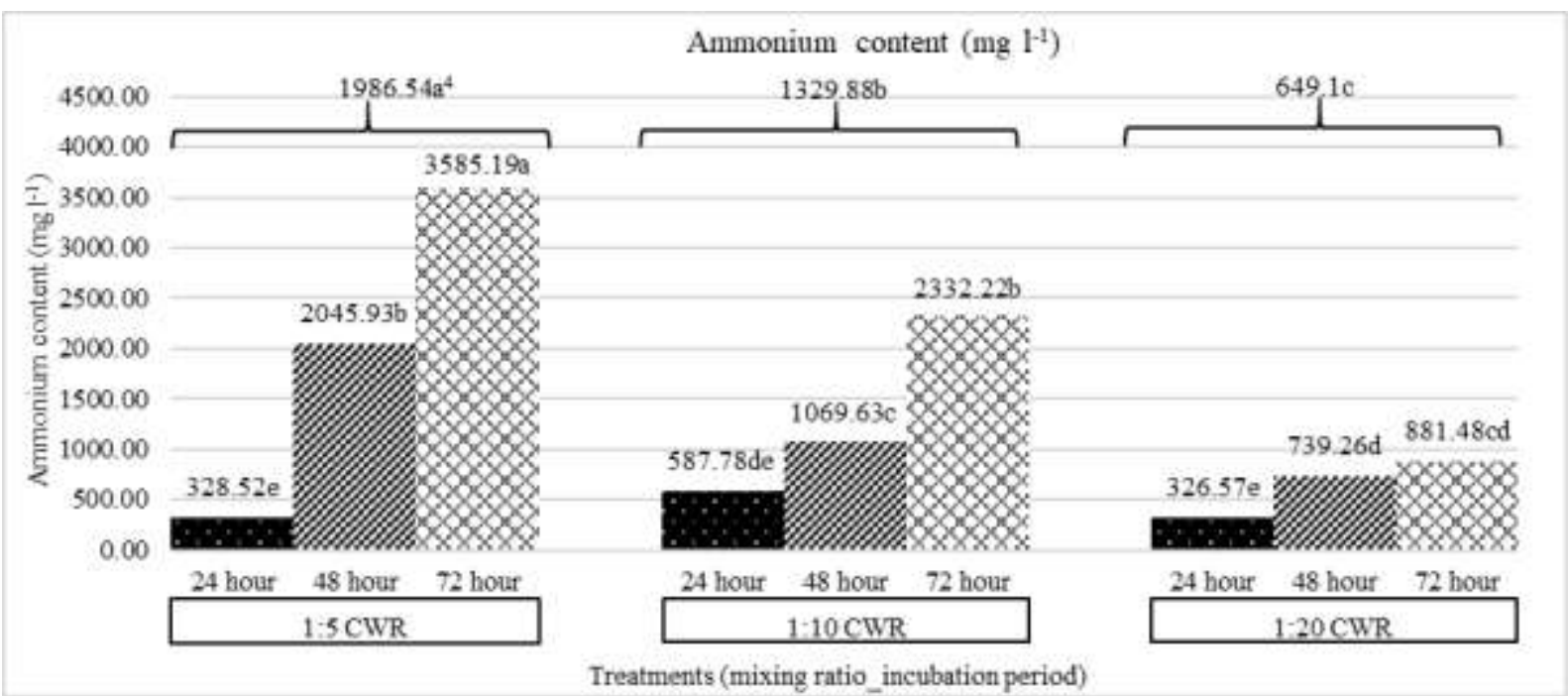

${ }^{4}$ Bars with the same letter are not significantly different $(\mathrm{p}=0.05)$

Considering only the mixing ratio, the tendency of ammonium concentration was similar to the nitrate concentration. It is also decreased significantly with increasing compost/water ratio. While the ammonia concentration of compost tea of $1 / 5$ compost/water ratio is close to $2000 \mathrm{mg} \mathrm{l}^{-1}$, the $1 / 20$ mixing ratio solution of ammonium concentration is $649 \mathrm{mg} \mathrm{l}^{-1}$.

Ammonium content also follows a similar trend to nitrate based on incubation time. Compared to the ammonium concentration of the solutions incubated for one day, the value increased significantly compared to the solutions incubated for several days.

Compost/water ratio and the incubation time has a significant effect on the concentration of nitrogen forms (Martin et al., 2012).

\section{CONCLUSIONS}

Based on our results fluctuations in $\mathrm{pH}$ values were low during the experiment. The $\mathrm{pH}$ was higher at the compost/water ratio $1 / 20(\mathrm{pH}=6.46)$, but no significant difference was observed between the $\mathrm{pH}$ of each mixing ratio.
The electrical conductivity decreased significantly with increasing compost/water ratio. The effect can be explained by the presence of larger amounts of dissolved ions in the more concentrated solution. The conductivity of compost teas incubated for three days was significantly higher than the solutions incubated for a shorter time.

Overall, more concentrated solutions have a higher nitrate and ammonium content. Furthermore, more nitrate and ammonium is dissolved from the compost when longer extraction time was used. It can be concluded that, the $\mathrm{N}$-forms present in the compost have a significant effect on the compost/water ratio and the incubation time.

\section{ACKNOWLEDGEMENTS}

This research was supported by EU grant to Hungary; GINOP 2.2.1.-15-2017-00043.

The publication is supported by the EFOP-3.6.3VEKOP-16-2017-00008 project. The project is cofinanced by the European Union and the European Social Fund. 


\section{REFERENCES}

Abbey, L.-Rao, S.A.-Hodgins, L.N.-Briet, F. (2013): Drying and rehydration of vermicasts do not affect nutrient bioavailability and seedling growth. American Journal of Plant Nutrition and Fertiliser Technology, Volume 3(1), pp. 12-21. https://doi.org/10.3923/ajpnft.2013.12.21

Alexa, L.-Dér, S. (2001): Szakszerü komposztálás. Elmélet és gyakorlat, Profikomp Kft., Gödöllő. pp. 264.

Csiba, A.-Fenyvesi, L. (2012): Facilities of poultry manure processing and utilisation with environmental technologies. Ageing Conference, Valencia, Spain, July 8-12, 2012.

Edwards, C.A.-Arancon, N.-Greytak, S. (2013): Effects of vermicompost teas on plant growth and disease. BioCycle, Volume 47, pp. 28-31.

Epstein, E. (1997): The science of composting, Technomic Publishing Company Inc., Lancaster, Pennsylvania, USA. pp. 487.

Gaál, K. (2011): Trágyakezelés- és hasznosítása a baromfitelepeken. In: Bogenfürst, F.-Horn, P.-Sütő, Z.-Kovácsné, Gaál K.Kovács, G.: Baromfitenyésztés. Egyetemi jegyzet, Kaposvári Egyetem; Pannon Egyetem; Nyugat-Magyarországi Egyetem. p. 254.

Georgakakis, D.-Krintas, T. (2000): Optimal use of the Hosoya system composting poultry manure. Bioresource Technology, Volume 72, pp. 227-233.

Gorliczay, E.-Pecsmán, D.-Tamás, J. (2018): Testing laboratory parameters of compost tea. Acta Agraria Debreceniensis, Volume 75(1), pp. 31-36. DOI: 10.34101/actaagrar/75/1642

Hosoya \& Co. (1996): Hosoya Manure Fermentation System. Hoyosa \& Co., 412 Fukaya, Ayase-Shi, Kanagawa-ken 252, Japan.

Ingham, E.R. (2005): The Compost Tea Brewing Manual: Latest Methods and Research. Soil Food Web, Corvallis, OR. pp. 1386.

Islam, M.K.-Yaseen, T.-Traversa, A.-Kheder, M.B.-Brunetti, G.Cocozza, C. (2016): Effects of the main extraction parameters on chemical and microbial characteristics of compost tea. Waste Management, Volume 52, pp. 62-68. https://doi.org/10.1016/j.wasman.2016.03.042

Kim, M.J.-Shim, C.K.-Kim, Y.K.-Hong, S.J.-Park, J.H.-Han, E.J.Kim, J.H.-Kim, S.C. (2015): Effect of aerated compost tea on the growth promotion of lettuce, soybean, and sweet corn in organic cultivation. Plant Pathol. J., Volume 31, pp. 259-268.

Litterick, A.M.-Harrier, L.-Wallace, P.-Watson, C.A.-Wood, M. (2004): The role of uncomposted materials, composts, manures, and compost extracts in reducing pest and disease incidence and severity in sustainable temperate agricultural and horticultural crop production - A review. Critical Rev. Plant Sci., Volume 23, pp. $453-479$.
Martin, C.C.G.S.-Dorinvil, W.-Brathwaite, R.A.I--Ramsubhag, A (2012): Effects and relationships of compos type, aeration and brewing time on compost tea properties, efficacy against Pythium ultimum, phytotoxicity and potential as a nutrient amendment for seedling production. Biol. Agric. Hort., Volume 28, pp. 185-205.

Martinez-Suller, L.-Provolo, G.-Brennan, D.-Howlin, T.-Carton, O.T.-Lalor, S.T.J.-Richards, K.G. (2010): A note on the estimation of nutrient value of cattle slurry using easily determined physical and chemicalparameters. Irish Journal of Agriculture and Food Research, Volume 49, pp. 93-97. Retrieved from http://hdl.handle.net/11019/171

Pane, C.-Palese, A.M.-Spaccini, R.-Piccolo, A.-Celano, G.Zaccardelli, M. (2016): Enhancing sustainability of a processing tomato cultivation system by using bioactive compost teas. Scientia Horticulturae, Volume 202, pp. 117-124. DOI: 10.1016/j.scienta.2016.02.034

Scheuerell, S.J.-Mahaffee, W.F. (2002): Compost Tea: Principles and Prospects for Plant Disease Control. Compost Science and Utilisation, Volume 10, pp. 313-338. http://dx.doi.org/10.1080/1065657X.2002.10702095

Sequi, P. (1996): 'The Role of Composting in Sustainable Agriculture'. In: de Bertoldi, M.-Sequi, P.-Lemmes, B.-Papi, T.: Proceedings of The Science of Composting: Part I. Glasgow, Blackie Academic \& Professional. pp. 23-29.

Sherstha, K.-Shrestha, P.-Walsh, K.-Harrower, K.-Midmore, D. (2011): Microbial enhancement of compost ex-tracts based on cattle rumen content compost-characteri-sation of a system. Bios. Biotech., Volume 102, pp. 8027-8034.

Sujesh, S.-Murali, T.-Sahithya, K.-Nilanjana, D. (2017): Preparation of compost tea and its utility as a plant growth promoter. Res. J. Pharm. Tech., Volume 10, pp. 3115-3122.

Sulzberger, R. (2006) Komposzt, föld, trágya. M-érték Kiadó, Budapest. pp. 7.

Szabó, L. (2016): Hosoya trágyakezelési technológia, Gödöllő.

Zaccardelli, M.-Pane, C.-Villecco, D.-Palese, A.M.-Celano, G. (2018): Compost tea spraying increases yield performance of pepper (Capsicum annuum L.) grown in greenhouse under organic farming system. Italian Journal of Agronomy, Volume 13(3), pp. 229-234. https://doi.org/10.4081/ija.2018.991 
